\title{
中国食酢の醸造技術について $(2)$
}

包啓安

\section{2. 現代食酢の醸造技術}

現在食酢の醸造技術とは大体二十世紀によく行われて いる生産技術である。伝統食酢醸造技術と新型製酢技術 汇分けて紹介することにしよう。伝統的な食酷醸造技術 は古代の醇造技術に継ってその本質を保って風味が最も よい方法である。清徐老陳醋と鎮江香醋と四川保寧嘫醋 は固体酶酸発酵法の典型である。清徐老陳醋は山西老陳 醋の代表であって, 高梁を原料とし糖化とアルコール発 酵は「大䅈」によって濃醪状態で行う技術である。鎮江 否醋は主として糯米を原料に使い，「小楼」を糖化発酵 剂として液体で糖化とアルコール発酵を行ってから固体 酢酸発酵を行ら工程である。四川保寧猌醋は現在四川溇 醋の代表的な生産技術である。全過程は固体発酵で完遂 する醇造技術である。永春老醋は紅麳を糖化剂として液 体発酵を行って造った米酷の典型である。それらの醸造 工程が違っているので, 風味も全然違って来る。

永い間，食酢工業は伝統的な製造技術を踏襲してお り, 他の醸造工業に比べて数多くの問題が残されている 状態である。近年, 食生活の向上に伴い, 食酢の需要の 伸長と品質の高級化が要望されている。また目覚しい科 学技術の進展の影響を受けて新規技術の導入と改革注 ってそれ対応しようと努力しつつある。製當の方では 純粋培養によって麩麴を造り, 糖化力を上げるため, 変 異菌株を作り出して, 食酢の澱粉利用率を大幅汇高めて いる。アルコール発酵を効率的に行らため, 発酵力の強 い酵母を使うようになった。省力化の面からも伝統的な 固体酢酸発酵法の切り返しを廃して汲及掛㤝固体発酵を 採用するものがあり，末たは全面発酵法を導入し，元の 風味を改善するため, 多菌株で発酵法を行ら技術も開発 されている。無蒸煮糖化技術もよく行われている。これ らの生産技術を新型製酶技術に一括してその大概を紹介 することにする。

\section{（1）伝統製酢技術}

中国の伝統食酶醇造技術には固体眽酸発酵之液体食酢 発酵々の二大種類がある。固体酷酸発醅には清徐老陳醋 々鎮江香醋と四川保寧撚醋がその代表的なものなので,

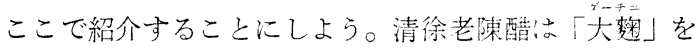
糖化剂・発酵剂とする典型的な生産技術で, 鎮江香醋は 「小猌」を使って米酢を造る例で市る。

四川猌醋冲隺の中に存在しているアミラーゼを主汇利 用する糖化方法と，自然に混入した酵母や䣷酸菌による 製酢法である。液体眽酸発酵法法永春老醋之夏門白醋等

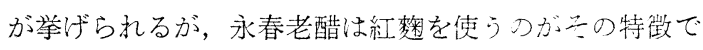
ある。

\section{1）清徐老陳醋}

清徐は山西省太原市付近の一県名であnて, 老陳醋は 永く熟成した食酶といら意味である。无の生産技術活既 に三百余年の歷史をもち，山西省に伝放って，山西老陳 醋の代表的なものになった。

製酢の原料となるものは非常に多いが，山四では長年 の経験からすると高梁が最もよいとしている。清徐老陳 醋に用いられている糖化剂と発酵剂计大麦之踠豆を原料 とする「大椈」である。それは生の觳類を破砕し，米で かためた磚のように成型したものに自然にカビを生やし た麴である。つぎにその製椈，仕込み・製成などの工程 を紹介する。中国の伝統的な濃醪糖化, 濃醪アルコール 発酵, 固体酷酸発酵である並行複式発醉技術の概要をう かがい知れよう。

\section{製 椈}

原料大麦と豌豆との割合は $70: 30$ の重量比である。 よく混合して粉砕する。以前は石碾を使っていたが，現 在は破破機を使うようになった。元つ破呼程度は製数の 品質に大きく影響するので，熟練な手法之淮かな経験に よることが多い。あまり荒いと「整坯」(製整原料で成型 して未だ楝になっていない半成品）の隙目が多過ぎて製 宷中に品温が容易に高くなって，カビの繁殖があまりよ くならない技それがある。あまり細くなる上出来た棃は 緻密になってカビの繁殖が遅くて赖坏つ真中まで伸長出

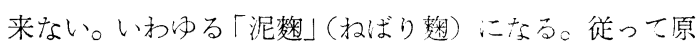
料の粉砕の程度は最も重要な作業である。粉砕の程度法 季節にもよるが夏はやや粗い方がよく，冬は少し細い方 が良い。

$8 \mathrm{~kg}$ 粉砕した原料付し $4.5 \mathrm{~kg}$ の水を加えるが，季 


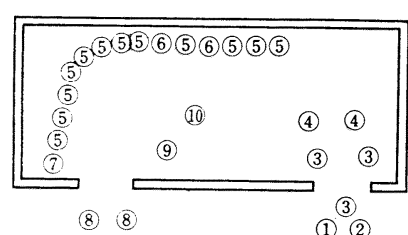

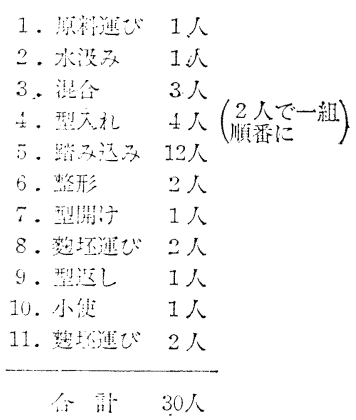

第 9 図 踏み込久場の配置

節によって調節する必要がある。よく混合してから木製 型に入れる。以前は人工的に踏久込んで磚の形に成型し たが，今では踏込機を使うようになった。一枚の稞坯を 造るには約 $2 \mathrm{~kg}$ の原料を必要とし, 踏み込んだものは 約 $3.5 \mathrm{~kg}$ ，出来上がったものは約 $1.5 \mathrm{~kg}$ である。粨の 踏又込又は約 30 人を要する。踏及込及場の配置は第 9 図の如くで㐫る。原料を装入した䴯型は運んで踏み込ん だ後，それを心っくり返して三番目の人に渡して踏及込 ませる。四番目の人涂計な原料を取り去って，檞の表 面を平らにし，きれいにした後五番目の人に渡して踏み 込ませる。六番目の人仙きれいにしたら七番目の人に渡 して踏み込ませる。以後の人は踏み込むたびにひっくり 返してから次の人に渡して踏み込ませる。十二人の踏及 込みを続けるのは必要な硬さにするためである。もし踏 み込及不充分であると愁室に引き込んでからこわれ易 い。最後の人型を叮き，楼坏を取り出して棚において から猌室に運搬する。定まった行列に従って積み重㸚る。 踏及込みで大切なことは，固く踏む力が均一なこと と，厚さも同じにすることである。厚さがあまり違うと 製杽のうちに品温や繁殖の程度と出来上り時間などが違 って来て，取り扱いの困難之品質の違いを招く。

昔から夏に踏み込みを行って来たが，三伏（夏至約 21 日目）の時は, 空気中の微生物が多く, カビ付きが早く て均一である。品温の調節も容易に行われる。従って 「伏䊝」の品質は上等である。現在はこの慣例を破って ほかの季節にも踏み込みを行っている。

㱀室の地面に先ず粐を薄く敷いてその上に麴坏を2〜 3 層に積み重㸚る。その間に太い蕫で摤んで，その間隔
は 1 2 cm 位がよいが，気温によって調節することが 大切である。增産するのであ机ば， 3 層に重悋て，その 間隔を少し大きくすればよい。全部を引き込んだら，葦 の岸で取り園えで，その上にも蒂で覆い，戸や空を閉じ て䴹坏の品温と湿度を保つようにして和く。棅室は長年 に亘って使うので, カビがいっぱいなので, 榃坏にも充 分につくのは当然である。も乙温度が $15^{\circ} \mathrm{C}$ 以上に上が って湿度も適当であればカビが速やかに繁殖して来る。

引き込んだ $2 ， 3$ 日目に麳坯の表面にぶつぶつと白い 菌系が生じてきて胡麻のように見兄る。「芝藏麴」と呼 んでいる。あまり多くとも，少なくてもよくないといわ れている。この時, 品温も次第に上昇してくるので莃を 取り去って温度の降下を計る。つついて一回目の手入れ をする。この段階を「潮火」という。

手入れは数坏を壁の方の通路にひっくり返す。以後の 手入れをするたびにこのように麭坯の積み替えを行う。 順に上層のものを下層に, 最後に最も下のものは最上の 層になるわけである。かつ一枚の䊝坏の下面を上面に向 らよう取り変方るのである。一回目の手入れは元の 3 層 を 4 層に変える。数坏の排列形式は元の 柱状積から第 10 図の如く「品」字の積み方に変る之同時にその間隔

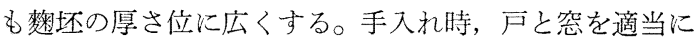
開けて，室の温度と湿度を降下する。このような手入れ を5回行うのが一般的で茄る。手入れを行うたびに麳坯 の層数も増していくが 10 層の高さまでで止め, 㭡坏行 列の距離も手入れのたびに従って增す。最後の手入れに 当って覆いを取って第 11 図の如く「人」字の形式に積 み替兄して数を乾燥する。

上に述べた手入れの作業から見ると，手入れの目的は

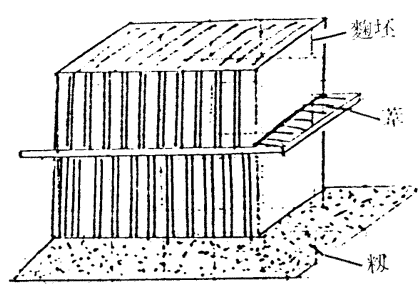

第 10 図「品」字の積夕方

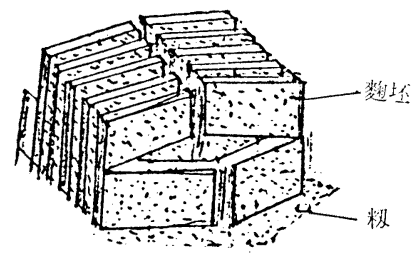

第 11 図「人」字の積み力 


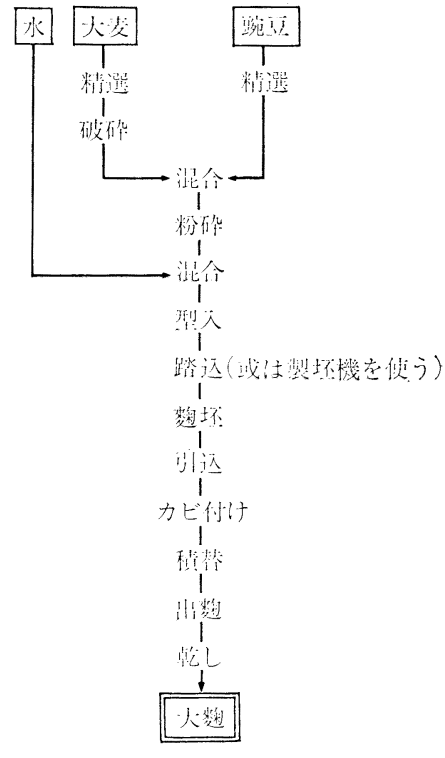

第 12 図 大麴の生産フローシート

熱の蒸発面積と空間を增加することであって，品温の降 下之粎坏間の温度と湿度を調節するためである。カビの 生育と増殖をよく揃兄，出樬時の成熟を均一にするため 考案したものである。

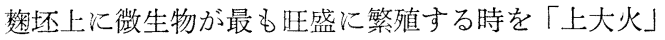
といい，この段階では手入れをするには整坏の重さ（重 量）によく注意しなければならない。軽いのは麴の繁殖 が速く，重いものは繁殖が遅い。それで前者を底層ある いは外側におき，後者は上層あるいは中央において，す べての䞟坏とよく揃うよう熟成することである。

「潮火」の段階で麴室の相対湿度は速く下がっていく が，以後は大体 $60 \%$ 位に保つ。「潮火」の時期が過ぎて も品温の上昇は続ける。相対湿度は徐々に下がってい く。この段階を「胎火」と称している。カビが迅速に麴 坏の内部まで繁殖し，破精込みのよい時期である。この 時, 品温の最高段階で,「大火」と称し, 最高は $50^{\circ} \mathrm{C}$ ま で上昇させ約 $5 \sim 6$ 日間続ける。これから品温が徐々に 下がって行く。もし黒豆の代りに踠豆を取り入れれば, 「大火」期間は $2 \sim 3$ 日でよい。「大火」期が終ると微生 物の繁殖は衰退期に入って,「干火」(あるいは「跌火」 期ともいう）と呼ばれる時期江入る。その後の品温は徐 々に室温まで下がり, 熟成する。保存するため, 麴の畭 燥をする。引込久から出麴まで約半月かかる。

大麴の生産フローシートは第 12 図の如くである。

発 酵

清徐老陳醋の発酵は糖化, 酒化の濃醪状態に相俟って 行方九る並行複発酵と固体酷酸発酵を行ら二段発酵方式 である。中国北方で盛んに行われている伝統的な製造法

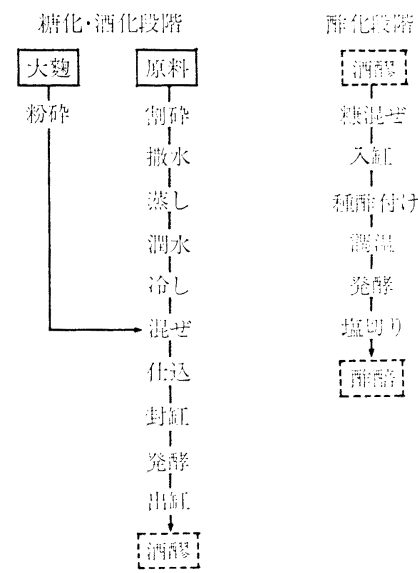

第 13 図 清徐老陳醋にお汁る発酵のフローシート

であって，その製造工程をフローシートで示せば第 13 図の如くである。

a. 原料処理

原料怯高梁で， 1 粒を 4 〜片ぐらいまでひき割って 使うのが伝統的なやり方であるが，今で虫やや細く粉砝 したものを使う方が多くなって来た。30 kg の割り砕い た原料汶対して $37.5 \mathrm{~kg}$ の水を加えて均一に混合し， 半日堆積して充分に水を吸わせる。夏には酸敗を防ぐた めそれを挾げて擋拌し，水分を吸わせて直ぐ㽀隹入れて 蒸す。蒸したものは非常にあっさりして少しの粘り気も 感じさせない。充分に熟した原料であ䃼ば，高梁の半量 の水を加光て潤水する。充分に浸してから拡げて冷却す る。夏は薄く拡げて擋拌して室温まで泠却し，趜と混ぜ て仕込さ。

b. 仕込多

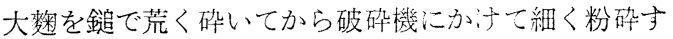
る。高梁 $50 \mathrm{~kg}$ に対し大棅 $31.25 \mathrm{~kg}$ の割合で大咆を伶 却した高梁に京いて混ぜる。発酔がまに原料 $60 \mathrm{~kg}$ を入 れ, 冷した挴湯 $90 \mathrm{~kg}$ を仕込水として加兄る。乞の温度 は 17〜18 $\mathrm{C}$ でよい。夏の仕込温度は低い程よい。アル コール発酵や㼍酸発酵や薰䤃（酶䤃を $70 \sim 80^{\circ} \mathrm{C}$ の温度 であぶって加光て香味や色沢を出す作業をいら）等作業 は同じ作業場で行うのが普通である。こういう部屋の室 温は割合汇高い。冬でも $27 \sim 28^{\circ} \mathrm{C}$ の室温が得られるの で，アルコール発酵は迅速佁まる。2 日目で $\mathrm{CO}_{2}$ 気 泡がぶくぶく出るようになってくると品温も上昇し， 3 日目では発酵が盛んになって品温も $37 \sim 38^{\circ} \mathrm{C}$ まで上昇 する。4日目には発酵がやや弱くなって, 品温も少し降 下する。6 7 日目主発酵が終って紙泥（焼け土・紙と 水を練り合わせたもの) で目張りをする。アルコール発 酵を続け，12〜14 日目でアルコール 発酵が大抵終る。 
上澄が出て, 酒の匂いも強くなり, 酸味を带び, 粕色も 紅褐色になることが順調な発酵の徴候である。

\section{酢酸発酵}

老陳醋の酶酸発酵は固体発酵法を採用し，成熟したア ルコール発酵の醪を擋拌して取り出し, 栗棣などの充壃 料を加えてよく混ぜる。糠の使用量は原料 $60 \mathrm{~kg}$ に対し $50 \mathrm{~kg}$ の割合でよい。もし㯨糠が粗い場合はやや減らし てもよい。あまり細いとやや多く加える必要がある。轪 を用いると製品の品質を高める利点があるので一般に充 填料の 2 割を添加する。よく混合した原料を午に半分位 まで入れる。その表面を平らにし一日間放置してから $5 \mathrm{~kg}$ の 3 日間酶酸発酵酢䤃（固体も万み）をかまに堆 積して酷酸菌の種付汀をする。これを「引火」という。 缸に草で編んだ蓋をして保温する。約 2 日間経つと品温 が漸く上昇し，上部の酢酸を手で少し緩めて（擋拌では ない）空隙を増して空気を酢酸菌に供給し，その增殖を 促す。3日目に品温は更に上昇して酢酸発酵の旺盛な段 階に入り発酵は下部になで及ぶ。つぎに「引火」をそば に積んで，手を酶䤃の底部まで伸ばして酶䤃を下から上 へ切返し，「引火」を切返したところに積んでおく。そ してその半分の酶䤃を同じように切返し，「引火」をま ん中に積んでおく。4 日目になると酢酸発酵の最盛期に 入り, 酢酸菌がよく増殖したら $5 \mathrm{~kg}$ 位取り, 種酢とす るっこの時に温度が $45^{\circ} \mathrm{C}$ まで上昇して来ることもあるの で, 酢䤃の徹底的な切返しを行う。切返しは伝統食酶醸 造に最も重要な作業である。それは酷酸の形成に重要な 役割を果しているばかりでなく, 製品の風味にも大いに 奇与している。切返しの操作は, 手掌で出来るだけ塊り を揉み活ぐし, 均一に混ぜることが必要で, かつ丁寧に 行うことが肝要である。以後, 毎日, 朝と夕方で切返し を 1 回行って，ての品温を $40^{\circ} \mathrm{C}$ 程度に保持することを 続ける。数日後, 品温が徐々に下がって来る。この段階 を「減火」と呼んでいる。9 10 日目になると酢酸発酵 は衰兄て品温も著しく降下して熟成期に入る。従って酢 酸発酵時期の技術管理は適時手入れをして, 酰䤃から蒸 発潜熱を奪い, 品温の急昇を防ぎ, 酢酸菌の增殖と代謝 を適切にすることが大切である。

酶酸発醅が終机ば直ちに塩切りを行う。原料 $50 \mathrm{~kg}$ に 対し食塩 $3 \mathrm{~kg}$ を加光, 充分に混ぜ, 酢酸菌の活動を止 めて「櫄䤃」あるいは「淋醋」を行う。

\section{淋 醋}

中国では，伝統の固体発酵食酢の分離で圧搾法を取る

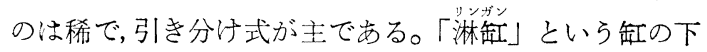
部に呑み口を設けて，缸底にいくつかの拱形瓦を入れ て，上汇蔁蒂を敷いて熟成した酷醅を入れる。一般的に は二番酷液を加えて一晚浸漬してからその液汁を流出さ
(外觬)

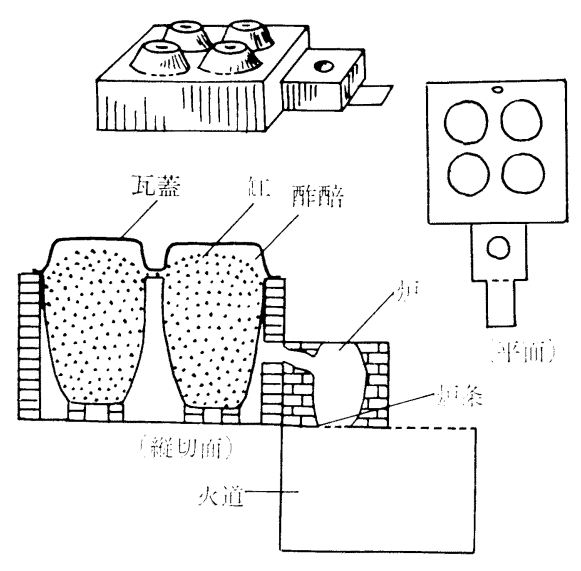

第 14 図葽 䤃 炉

せる。この作業を「淋醋」といら。この酰液を「頭淋」 （即ち一番汁）という。火入れをして薰䤃を入れた淋罈 に加兄て流出させると老陳醋の中間製品となり，同じ方 法でもう 1 回淋醋を繰り返して「陳䤑」(aging) をする と老陳醋となる。この粕にはまた可溶性成分を相当含ん でいるので, 清水で二回淋醋を行って得られた二番液汁 を「醋水」と呼び，醋淋を造るのに用いる。冬になると 気温が低くなるので「淋醋」に用いる水は惹沸した方が 上い。

\section{瞢 䤃}

「薰䤃」は山西醋製造工程の一大特徴で，伝統的な方 法は第 14 図の如く薰䤃炉の中で行う。まず酢䤃を黄缸 に入れ，一日隔きにつぎの缸に移していく。この作業を 4 回絽り返す之熟成する。薰䤃の温度は, 欫口から 10 $\mathrm{cm}$ のところで約 $90^{\circ} \mathrm{C}$ 付近であり, 䍂底は約 $100^{\circ} \mathrm{C}$ ある

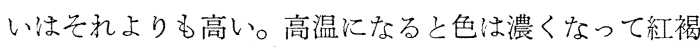

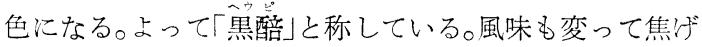
た香りがする。魚䤃炉の火はあまり強くない方がよい。

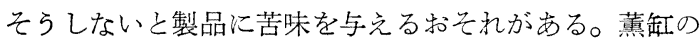
温度は場所によって同じではないが 4 回切返しを行うの で均一に熱せられると考える。現在こういう直火で薰醅 を行う工場は稀で，蒸気や回転缶を使うようになった。

\section{陳 醇}

山西老陳醋は必ず「陳䁔」といら工程を経過しなけれ ばならない。つまり，一番酢を卸に入れて庭や広場の日 当りのよいところに放置する。夏を経て水分が蒸発す る。冬には凍って氷として水分を取り除くことによって 大いに濃縮される。この長い時間に各種の生物化学反応 が起こって色沢, 香り, 味などはよく改善される。それ で老陳醋の総酸とエキス分等の含量は高くなって, その 
第 1 表 老陳醋和新醋成分の比輺

\begin{tabular}{|c|c|c|c|c|}
\hline & & & 老 陳 醋 & 新 \\
\hline & \multirow[t]{2}{*}{$\neq \quad$ r } & 分 & $33.6 \%$ & $9.12 \%$ \\
\hline 比 & & 重 & 1. 1821 & 1.0671 \\
\hline 厉 & & 5 & $12.03 \%$ & $3.09 \%$ \\
\hline 還 & $\vec{\pi}$ & 樯 & $5.20 \%$ & $1.62 \%$ \\
\hline 総 & & 酸 & $16.81 \%$ & $10.43 \%$ \\
\hline 食 & & 塩 & $7.32 \%$ & $2.05 \%$ \\
\hline 揮 & 発 & 酸 & $3.45 \%$ & $6.01 \%$ \\
\hline 不 & 揮 発 & 酤 & $8.91 \%$ & $1.41 \%$ \\
\hline & 土 ス & $n$ & $3.73 \%$ & $1.95 \%$ \\
\hline
\end{tabular}

保存性が大いに高められる。陳醸された製品之陳醸しな い食酷の成分は第 1 表の如く大変違っている。

\section{2）鎮江香醋}

鎮江香醋は中国の名産物であって, 1850 年から生産 されたといわれている。昔から唒順之萬美といら酢屋が 有名で, 紹興または上海, 南京の黄酒粕を原料にして醸 造したものである。酒粕の生産が限られて市場の需要を 満足することが出来なかったので，糯米を原料之する食 酢を醸造するようになった。るず酒粕を原料とする醇造 法について述べることにしょう。

酒粕を原料とする鎮江香醋は日本の粕酢の䁔造法之違 って酒粕の熟成を行わず，直ちに水を加光て液体酷酸発 酵を行らのである。酶種には熟成した酶䤃を使う。その 醀酸菌の繁殖を確実に拉大していく方法は極めて丁寧に 行うが，操作は繁雑で，から多くの労力を要する。しか し，この操作によって多くの空気之微生物を引き込ん で, 食眽の風味に深く関係していると考光る。参考ま で，その発酵方法を紹介する。

発酵容器は缸を使い，酒粕 $250 \mathrm{~kg}$ と水 $80 \sim 90 \mathrm{~kg}$ を 入れ，混合して均一にする。粐をとの上に二寸位の厚さ に敷いて熟成した酷䤃を少し入れ，酢酸菌の種付けとす る。上部の酢粕之酢䤃と粐と三者をよく混ぜ， $3 \sim 4$ 寸 厚さの粐で覆っておく。夏では約 $1 \sim 2$ 日間, 冬では 5 〜 6日間経つ之熱が生じて品温が次第に上昇して来る。 相当熱くなると粐の $2 / 3$ を取り，西之の $1 / 3$ を卸のそば に打き，熱が生じた酒粕の $2 / 3$ を取って二番目卸（半分 の酒粕を入れ）に移し，少量の粐を入れて上部の酒粕と 充分に混ぜ，通気状態をよくする。3〜4才位の厚さの 粐を敷いておく。一番目缸については, 残された $1 / 3$ 粐 と発熱酒粕を上部の酒粕と充分に混ぜ， $3 \sim 4$ 寸位の厚 さの粐で覆って特く。二番目卸は一日間を経て熱が生 じ，前に述べたように上部の粐を $2 / 3$ 取って三番目の卸 に移すと同時汇一番目䍂から発熱酒粕を $1 / 3$ 残し，㐫之 の $2 / 3$ を二番目缸に加光る。二番目缸に残された発熱酒 粕と粐は上部の酒粕と充分に混ぜてから $3 \sim 4$ 寸の厚さ の粐で覆っておく。このように二番目午は $2 / 3$ 発熱酒粕
を三番目缸に移すが，一番目缸から同量の発熱酒粕を得 られたわけでこれを残された粐と上部の酒粕とよく混 ぜてから $3 \sim 4$ 寸の厚さの粐で覆っておく。三番目卸は 二番目御から得られた発熱酒粕に少量の粐を加兄, 上部 の酒粕とよく混ぜてから前と同じように $3 \sim 4$ 寸の厚さ の粐で覆って㻉く。翌日の朝に一番目, 二番目, 三番目 の䍂の酢䤃には酢酸菌が增殖するため品温も上昇して来 る。三番目欫の $2 / 3$ の粐と発熱酒粕を取って四番目の空 いている軋に移す。三番目の䍂に残された $1 / 3$ の粐と発 熱酒粕は上部の酒粕とよく混ぜ，更に二番目缸から移し て来た $2 / 3$ の粐之発熱酒粕之充分に混ぜて， $3 \sim 4$ 寸の 厚さの粐で覆っておく。同じ要領で一番目䍈から粐と発 熱酒粕を二番目に移す。四番目䍂の発熱酒粕之粐を一番 目の缸に移す。翌朝，この要領で順序上く発熱酒粕を移 していくが，12 日間経つと粐の量は徐々に増えてくる ので，半分畋入れの酒䤃も，順次いっばいとなる。この 時, 酒䤃は発酵して完全に酢化され，熱も生じなくな る。每日 1 回切返しを行い, 12 日後, 泥と苦塩と練った もので一寸の厚さに密封する。1 週間後活かの年に切り 替して同じように密封し，2週間後もう1 回切返しを行 って密封する。約 1 力月で熟成する。これは酷醅の固体 で「陳醇」を行ら方法である。

切返しを行らのは, 熱の発散と $\mathrm{CO}_{2}$ の排除並び汇空 気の供給をなすためである。淋醋の方法はやはり「淋 欫」を使うのが一般的なやり方である。一担 $(100 \mathrm{~kg})$ の酒粕と $1250 \mathrm{~kg}$ 粐から $720 \mathrm{~kg}$ の製品が得られる。

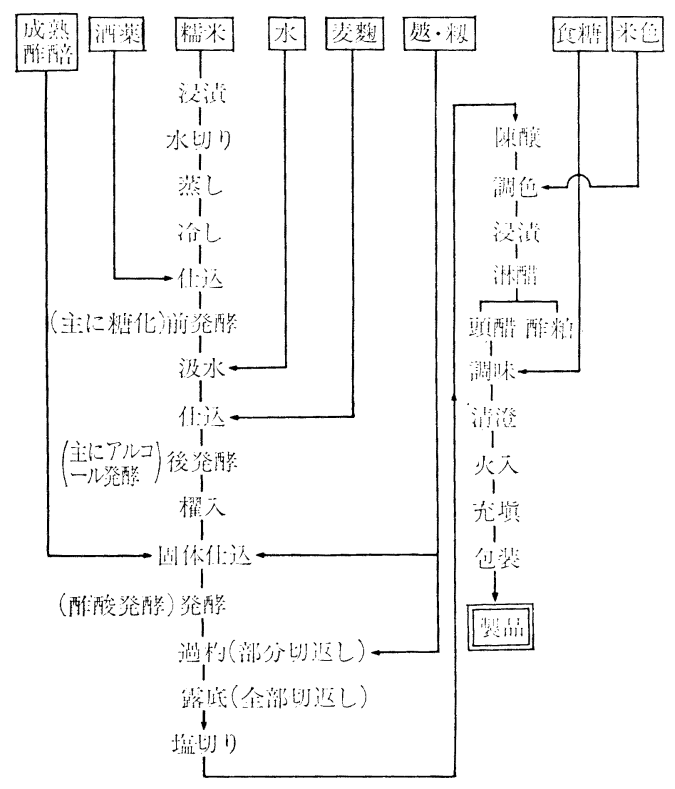

第 15 図 鎮江香醋の生産フローシート 
さて，つぎに糯米を原料にした鎮江香醋の醸造工程に ついて述べる。この工程の特徵は,「酒薬」を糖化剂と 発酵剂とし, 液体糖化とアルコール発酵を行う, 固体䣷 酸発酵の醇造法である。そこで糯米を原料とする鎮江香 醋の醸造工程をフローシートで示すと第 15 図の如くで 㐫る。

\section{製 剓}

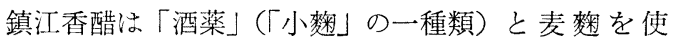
う。鎮江香醋の酢歩合は割合に高い。風味が独特である のは，この二種類の赖仕込みによるところが多い。

麦棦は黄酒造り及び香醋の製造に重要な地位を占めて いるが，それは，主にでん粉の糖化剂とし，また風味物 質の生成に関与している蛋白質の分解に重要な働きを果 している。麦榡は掛麳に相当し，生小麦を原料として使 っているが，昔は少量の大麦を混ぜることもあった。製 釉の最適季節は 8 月から 9 月の間で，ちょらど桂花が媄 いている季節であるから「桂花憗」と呼ばれていた。そ の製造工程をフローシートで示せば第 16 図の如くであ る。

篩で精選された小麦を水洗せずにそのまま $3 \sim 5$ 片に ローラーで䃩き割る。その $35 \mathrm{~kg} に 6 \sim 7 \mathrm{~kg}$ の水を加 兄て速やかに混ぜ，粒に白い芯がない上うに水分を完全 に吸斿せる。水分は多くて互いに粘着したり塊りになっ てはいけない。最後の小麦片の含水量は $21 ２ 4 \%$ 位で よい。長さ $100 \mathrm{~cm}$, 幅 $21 \mathrm{~cm}$, 高さ $14 \mathrm{~cm}$, 底がない木 型の下に稻歪を敷いて，拌水した小麦片を入れ，手で軽 く押し詰め, 平らにする。木型を取りはずし, 稲茠で軽 く楼を包んでおく。出来た䴶包久は円柱形で，約 9 10 $\mathrm{kg}$ の重さである。それを敕室に垂直的な行列になるよ らに積んでおく。行列の長さは 6 メートル, 幅は 2 メ トル位で，その間隔は 0.5 メートル位である。通気と 熱の発散をよくするため，上のように取り扱ったのであ る。原料や木型や稲橖等に付いた微生物は自然に生育し て品温が次第に上昇する。そこで空の温度と湿度を調節 して微生物の生育を促すことが大切で市る。もし室温が

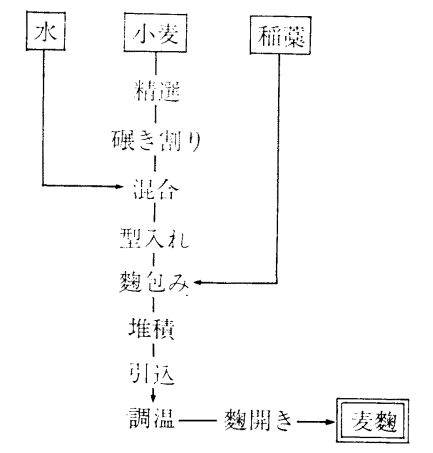

第 16 図 麦猌の生産フローシート $20^{\circ} \mathrm{C}$ から $38^{\circ} \mathrm{C}$ まで上がれば敕堆上の竹䉀を取る。 $45^{\circ} \mathrm{C}$ まで上昇すれば麳堆を覆った稲㗎を取り, 戸と空を開け て散熱する。7日目以後の品温は徐々に下がって室温に 近くなる。麴中の水分は蒸発されて菌系がよく伸びて硬 い塊りとなって，手指で挾んで力を加えて圧すると崩れ てしまうようになる。この時包んだ稲橖を取り去って䴿 の塊りを冷し部屋に堆積して貯える。

麦麲の塊りは軽く押し詰められたような外観をしてい るが，その組織は非常にゆるやかで，通気がよくて「大 楼」の磚状の組織と全く違っている。つまり通気のよい 組織状態であるので, 増殖して来るカビは好気性のアス ペルギルス・オリゼーが主なるもので，リゾープスはそ のつぎのものである。長い時間の醸造経験によると黄緑 色胞子が多い程その品質もよくなる。このような麴を使 らと発酵が速く, 製品も品質もよい。もちろん, 製楝の 条件によってはアスペルギルス・オリゼーの繁殖があま りよくない麴が出来ていることも相当多い。概してこう いら麦䊝の品質はよくないとされている。アスペルギル ス・オリゼーを主とする酵素系は「大麴」と違って, 蛋 白質分解酵素が強いのが特徵である。これは製品のよい 風味に深く関連していると思われる。多くのアミノ酸を 含んでいる黄酒や食躙は昔から麦䴯が使われて来たこと からその重要な働きが宿われる。

「酒薬」は「小䊝」の一種類であって, 浙江及び江蘇に 産するものが有名である。その製造歷史は古い。原料の 配合割合, 製造工程の違いによって各々の特徴をもって いる。その形状は「大䅘」より小さくて餅状となってい るものが多いので，「大棅」に対して「小麴」といら名 を付けられたのである。しかしながら，それに繁殖して いるカビは主としてリゾープスであることが大数と同じ である。酵母も相当含んでいるので発酵剂として使われ ている。薬草を多く使う工場もある。鎮江香醋に使う酒 薬は生米粉を培地とし薬草を添加して造ったものであ る。

酒薬にはリゾープスの酵素系に豊富な $\alpha$-アミラーゼ とグルコアミラーゼを含んでいる。その割合は $1: 3.3$ で, アスペルギルス・オリゼーの方は $1: 1$ であって, グルコアミラーゼは測粉分子の $\alpha-1.4$ と $\alpha-1.6$ 結合鎖 の非還元性末端側からグルコース単位で切り,グルコー スを放出する。多数の酵母は活とんどグルコースしか発 酵できないので，もろみの発酵速度を律速する酵素とし て非常に重要である。この点からいえばリゾープスはこ の優れた酵素をもつわけである。なお，リゾープスの細 胞に有機酸を産する酵素を含んでいる。製品に不揮発酸 の含量を増して食酢の酸味によい影響を与える。鎮江香 醋の酶酸エチル含量が多いのは「酒薬」を使用すること 
飞よるためである。中国ではいわゆる清香型の白酒は, 酢酸エチルの含量が多い。その味が重く感じられ，また リゾープスには酵母のようなブドウ糖を発酵して酒精を 造る働きをもつといら特徵がある。これらの解明された 研究事実より，昔からリゾープス楼を使って黄酒や白酒 を醸造して来た原因がいくつか説明出来ると考える。な お，今でも黄酒や食酢の醸造にリゾープス麵と麦䊝を配 合して使っているのは如何なる働きによるか, もっと研 究する必要がある。科学と分析技術の進歩によって, 永 く神秘のベールに包まれた中国椈の働きが解明されると 考学られる。

第 17 困に「酒薬」の製造工程をフローシートで示し て，その製造法の概要を紹介する。

精選された米を水に浸漬し，冬では約 6 時間，夏は約 $2 \sim 3$ 時間かかる。水を充分に切って粉砕し，その一部 分を粉付けに使う。米 $15 \mathrm{~kg}$ 当りの薬草粉 $13 \%$, 梦種 粉 $2 \%$, 水 $60 \%$ 位を加え, よく混ぜて餅のようなもの を造る。これを平らに圧して，2 cm 位の太さの粒に切 り, 竹篩にかけて丸めて䊝坯とする。 $5 \mathrm{~kg}$ 米粉を取り, $0.2 \mathrm{~kg}$ 㮃種粉とよく混合して，その部分を箕の中に入 れる。丸めた䴹坯を水に漬けてから振動篩に入れてもら 一回振りながら粉を付け, 全部の粉を振りつけてしまら よらに水漬, 振りつけの操作を繰り返す。この丸めた䊝 生地を「酒薬坯」といら。それらを竹篩に入れて剓室に 運んで培着するのである。麴室の温度を $28 \sim 31^{\circ} \mathrm{C}$ に保 持してカビ付けを促進する。20 時間経つとカビが盛ん に増殖し, 品温は $33 \sim 34^{\circ} \mathrm{C}$ に上昇したところで竹篩の 上に覆った竹篩を取って品温を降下させる。24 時間後, 酵母生育しはじめる。室温を $28 \sim 30^{\circ} \mathrm{C}$ 位に保って,

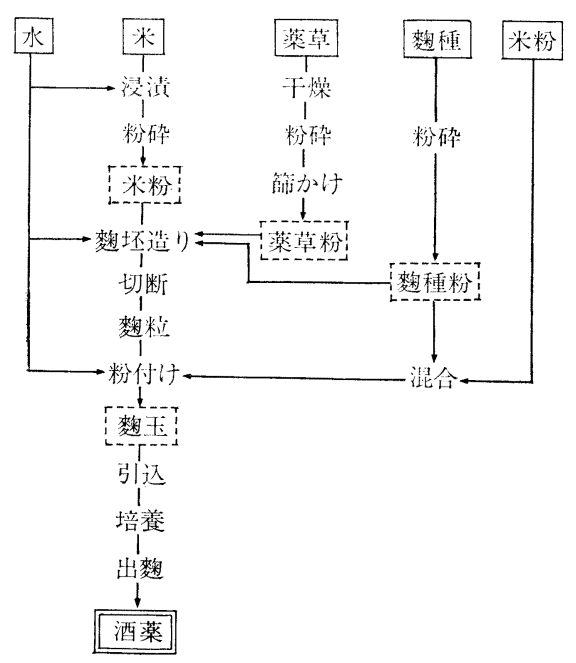

第 17 図 酒薬の生産フローシート
品温を 33〜 $34^{\circ} \mathrm{C}$ を越えないよう調節する。約 48 時間 後品温は徐々に下がって数は既に熟成しているので，乾 かして貯蔵する。全工程は約 5 日間かかる。

\section{発 酵}

精選された精米 $500 \mathrm{~kg}$ を水に浸漬する。夏は 15 時 間，冬は 20 時間を要する。浸漬した米は硬い芯がなけ れば漉して膂に入れ，流水でさらに洗い，水切りする。 粒の表面の付着水を除くのは, 蒸米の上权ばりを防ぐた めである。そうしてコシキに入れてよく蒸す。蒸し終っ た米はふっくらとし, 外面はやや硬く, 内部は軟らかで弾 力があり，上枚ばりのしないものがよい。冷水で冷や寸 のは屢々である。夏は $25^{\circ} \mathrm{C}$, 冬は $30^{\circ} \mathrm{C}$ ま泠却して 「酒薬」, $2 \mathrm{~kg}$ を加光, よく混ぜる。仕込時, 蒸米を $\mathrm{V}$ 形にし，まん中を寉ませておく。草で編んだ愳をし，温 度を保つのは杂菌の污染を防ぐためである。品温は 31 $\sim 32^{\circ} \mathrm{C}$ に保持するように低温糖化を行う。冬は稻橖で 発酵畋を圍んで保温するのが一般的である。約 60 - 72 時間が経つ之蒸米の糖化が進んで垔底から離れて浮び上 がって, 糖化液が寉みに溢れて来る。時々 $\mathrm{CO}_{2}$ の泡が 見光, 酒精も出来て, 還元糖は $30 \%$ 位になる。この段 階を前発酵と呼んでいる。

「酒薬」を加えた 4 日後，仕达水(糯米の $140 \%$ ) と麦 麴 $30 \mathrm{~kg}$ とをよく混合してもろみを少し薄めてつぎの アルコール発酵を適切にする。一般的にはアルコール発 酵を後発酵と呼んでいる。24 時間後檴入れをし，3 日 後, 毎日 $1 \sim 2$ 回椎入れをする。この段階は $13 \sim 14^{\circ} \mathrm{C}$, 夏の酒精含量は少し下るが $10 \%$ 以上が一般的である。 酸度は $0.8 \%$ 以下である。

酢酸発酵は固体発酵である。酷酸菌の増殖は, 順々に 拡大していく方法を取るのが效率的である。酒精もろ及 $165 \mathrm{~kg}$ を卸に入れ，麬 $85 \mathrm{~kg}$ を加え，撹拌して濃厚な もろ又にする。別に発酵良好な酶䤃を $2.5 \sim 3.0 \mathrm{~kg}$ を取 り, 少量の粐と水（冬は温水を使う）を加えて擋拌し て，上述したもろみの中央に入れて酢酸菌の種付汀とす る。䍂の表面に粐を敷いて保温して発醅を促す。約 3 4 日経つと上部の品温が上昇する。 $42^{\circ} \mathrm{C}$ に達すると上 部の発熱した酶䤃と下部の未だ発熱していないものの一 部分と粐を丁寧に混ぜて別の㞰に移す。この作業を「過 构」(切返し) という。毎日 1 回行い, 10 回で全部の酢 䤃を移してしまう。ちょうど一杯になる。「過杓」の温 度は $45^{\circ} \mathrm{C}$, 最高でも $48^{\circ} \mathrm{C}$ を越えないように注意する。 毎日の「過杓」を終ると元の酢䤃上に約 $4 \mathrm{~kg}$ の粐で覆 って保温しておく。同時に「過构」をしょうとする酢䤃 に必要に応じて少量の水 (冬は温水を使う) を加えて酒 精の濃度を減らす。「過构」といら作業は面倒くさく, かつ多大な労力を要するが，固体の酢䤃の酢酸菌を充分 
に增殖するため苦心した考案といわ祆ばならない。「過 构」を行ら時必ず粐を加えるのは醀醅を通気のよい状態 に保持するためで市る。「過构」が終ると酢酸発酵も最 盛期になり，品温を降下すると共に空気を酶酸菌に供給 するため，毎日切り返しを行ら必要がある。即ち，甲缸 の酶䤃を順々に乙卸に全部移してしまうのであって, こ の作業は「露底」之呼んでいる。7 日経つと品温は $45^{\circ} \mathrm{C}$ 以下に下がって来る。酢酸の含量も最高になる。酰酸発 酵が終ると缸每に食塩を $2 \mathrm{~kg}$ 加えてよく混ぜ，硬く押 し詰奶て上をポリェチレンフィルムで覆い，卸と接する ところに食塩で圧して空気が入らないよらにする。これ を「封竍」という。1 週間後に別の卸に移して密封し, 約 3 力月の「陳醮」を行う。

「淋釭」に充填前米色を加克て浸渞することと, 頭酢 に砂糖を加えて調味することが鎮江香醋の特徴である。 鎮江香醋の色沢は亮い深褐色で，とてもいい它いがす る。製品の総酸は $6.4 \%$ に達するが，あまり酢っぱい と感じられず甘くて旨い。アミノ酸が相当含んでいてア ミノ態窒素の含有量は $0.20 \%$ に達する。総エステルは $4.0 \%$ にも達している。

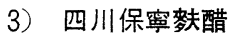

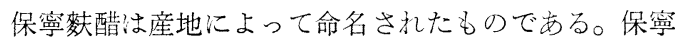
は現在四川嘉陵江上游の闑中県で, 昔は保寧府と呼ばれ

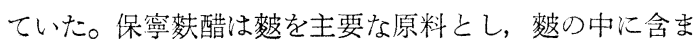
れているアミラーゼを利用して糖化を行うのである。

「酒薬」あるいは, 辣蓼汁 (蔡の浸出液)で培養された酵 母でアルコール発酵を行う。糖化やアルコール発酵, 酢 酸発酵は全部固体で行う。熟成には一年を要する。製品 は独特な風味をもっていて, 四川省の各地でこの醸造法 が広く採用されている。その生産フローシートは第 18 図のとおりである。

四川粼醋の醸造は酒薬（あるいは䓹の浸出液の添加） で糯米を糖化し，酵母るるみを造る時に薬草を混ぜるこ とが多い。蓼浸出液を造るには野生䓹を乾かして缶に貯 える。水で浸漬して 1 力月経つと使用出来る。糯米 30 $\mathrm{kg}$ を水で浸漬し, 米の白芯がなくなれば水切りして蒸 す。缸に水 $100 \mathrm{~kg}$ を入れ, 蒸米檪楼粉 $0.3 \mathrm{~kg}$, 䓹の

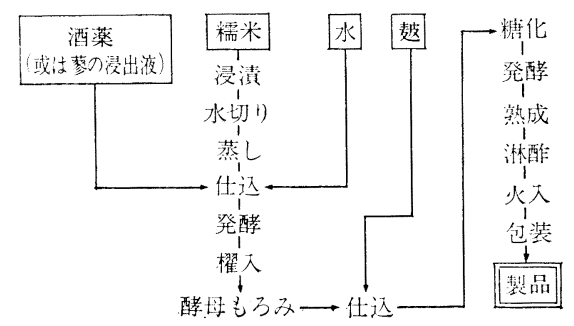

第 18 図 四川保寧焚醋の生産フローシート

第 83 巻 第 8 号
浸出液 1 1.5 kg とよく擋拌して蓋をする。冬では稲 蒠で欫を圍んで保温する。翌日発酵し始める。時々櫂入 れをし, 約 1 週間で発酵が終る。この時, 泡も消失し, 上澄みが現われる。これを酵母のもろみとし, 躲とよく 混ぜて固体発酵を行う。新鮮な麬 $650 \mathrm{~kg}$ を発醳槽に入 れ, 酵母醪とよく撹拌し, 水 $40 \mathrm{~kg}$ 加兄, 充分に撹拌 して 60〜 70 cm の愿さ江拡げて発酵する。野生酢酸菌 が同時に繁殖して酶酸発酵を営しで複式発酵が行われ る。酶酸菌の繁殖を促すために, 毎日一回切返しを行 万。2 日目に酰䤃の上部が発熱し始まる。5 日目は全部 の酢䤃は酢酸菌の增殖によって熱くなる。8日目から品 温は降下し始め 14 日間で酢酸発醳が完了し, 酢の香り が極めて強くなる。それを缸洁め込んで強く圧し，そ の上渓 $3 \mathrm{~cm}$ 厚さの食塩をまいて蓋をする。そのまま 庭で 1 年間の熟成を行う。淋醋は一般の通りである。 $650 \mathrm{~kg}$ の秡と $30 \mathrm{~kg}$ の糯米から $1,200 \mathrm{~kg}$ の食酢が得 られる。

\section{4）永春老醋}

永春老醋は福建永春県に産する名物である。それは紅 稞を使うので, 福建紅麴老醋とも呼ばれている。「老」は ひねたの意味で，同時て長時間熟成したといら意味も合 せ持っている。その生産の歴史も, 二百余年の古い歴史 をもっているといわれている。永春県あたりは食酢を醸 造する習慣がある。その製品は東南アジアにまで販売さ れている。永春老醋の総酸は $7 \%$ に達するが, 酸味が旨 くて芳香富む。その風味は独特で, 紅麴を使うことに より寄与されると考光られる。醉造全工程は液体で行う のもその特徵である。熟成方法も一般と違って, 違った 年度の酶醪を組み合せて 3 年間熟成する方法である。

糯米 $270 \mathrm{~kg}$ を水で充分に浸漬し, 西との蒸しを容易 にする。吸水速度は水温により異なるが，冬では 10～ 12 時間, 夏では 6 ～8時間でよい。吸水の終った米は 流水で洗い, 洗った水がきれいになれば水切りを行って 蒸す。蒸し時間は蒸気が米の全面に吹き拔けてから 15 〜20 分位で充分である。蒸気の吹き拔けを均一にする ために, 初めは薄く原料をならして, 下から蒸気が吹き 抜けてから，その部分に浸漬米を重㸚てゆく方法をと る。蒸し上がった米は夏では $35^{\circ} \mathrm{C}$, 冬は $38^{\circ} \mathrm{C}$ ま泠却 する。それに原料米の $25 \%$ の古田紅麴をむいてよく混 合して直ぐ缸に入れ， 2 倍の水を加えて保温する。水温 は季節にもよるが, 品温は $38^{\circ} \mathrm{C}$ に保つようにする。 24 時間経つと醪の液汁が甘くなるので, 再び $30^{\circ} \mathrm{C}$ まで泠 した技湯 $80 \%$ を加えてアルコール発酵を行う。品温は $38^{\circ} \mathrm{C}$ まで上昇するのが一般的である。以後は毎日櫂入 れをする。 5 日目では $20 \mathrm{~kg}$ の粳米で造った香味液 50 $\mathrm{kg}$ を加え，1日㧤きに 1 回擋拌する。この発醅醪に上 


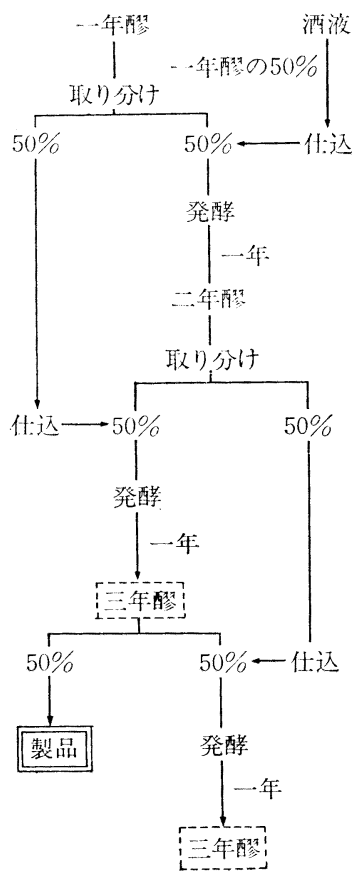

第 19 図 永春老醋の陳醸フローシート

澄みが現われ，紅酒粕が沈んでくれば擋拌を止め，早速 笑を差し込み，その中から酒液を汲久出す。この液汁 の酒精含量は $10 \%$ に達する。全工程に約 70 日間かか る。

酢酸発酵は天然から混入した酢酸菌によるが， 1 年発 酵の㼍醪を酥酛とし，3年間の熟成を行う方法を採用し ている。第 19 図の如く 1 年発酵した䣫醪の半分を眽酛 とし，酒液を入れ，残りの半量を 2 年間発酵した酢醪の 半分に入れて発酵を続ける。 2 年醪の残りの半分を 3 年 発酵醪の半量に加える。 3 年発酵醪の残りの半分を製品 として取り扱ら。

この操作によると, 永春老醋は約 2 年半以上の熟成を

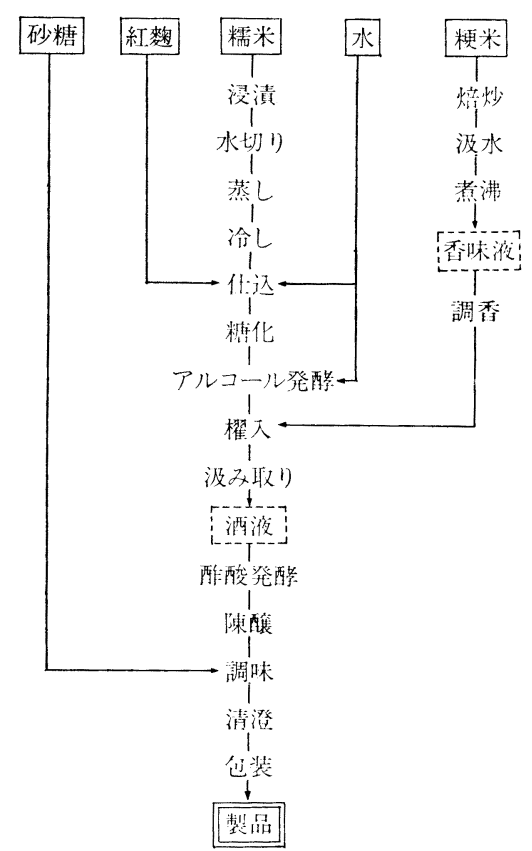

第 20 図永春老醋の生産フローシート

行らので，その品質が，よいはずである。1 年発酵醪に 酒液を加える時, 焙炒した胡麻を入れて調味する。表面 発酵であるから液表面に近い部分で発酵が起こるので, 品温も高くなる。それで每週 1 回擋拌をしてその温度差 をなくし，対流を起こして発酵を促す。品温を $25^{\circ} \mathrm{C}$ 付 近に保持し続けると光沢ある灰色の酷酸菌の皮膜が張っ て酢酸菌の繁殖が盛んになる。3 年の発酵で酢酸の濃度 が $8.0 \%$ になる。表面発酵法なので，この酸度に達し させることは，そう無理ではないかと思われる。糖分を 増すため $100 \mathrm{~kg} 3$ 年間熟成させた酢に $2 \mathrm{~kg}$ の砂糖を 加えて擋洋し，自然に沈測させて上澄みを汲及取って包 装して製品とする。その生産フローシートは第 20 困の とおりである。

(つづく) 